\title{
Primary Squamous Cell Carcinoma of the Breast: a Case Report and Immunohistochemical Features for Differential Diagnosis
}

\author{
Memenin Primer Skuamöz Hücreli Karsinomu: Olgu Sunumu ve Ayırıcı Tanı Açısından \\ Immunohistokimyasal Özellikleri
}

\author{
Peyker TEMIZ,, 1 Ali Rıza KANDILOĞLU, ${ }^{1}$ Gülin ŞİMŞEK, ${ }^{4}$ Teoman COŞKUN, ${ }^{2}$ Cihan GÖKTAN ${ }^{3}$ \\ Departments of ${ }^{1}$ Pathology, ${ }^{2}$ General Surgery, ${ }^{3}$ Radiodiagnostics, Medical Faculty of Celal Bayar University, Manisa; \\ ${ }^{4}$ Pathology Laboratory, Tokat State Hospital, Tokat
}

Submitted / Başvuru tarihi: 05.03.2008 Accepted / Kabul tarihi: 31.03.2008

\begin{abstract}
We present a 68-year-old postmenopausal woman with a rapidly growing right breast mass. It was diagnosed as "invasive ductal carcinoma" on tru-cut biopsy owing to infiltrative pattern and c-erbB-2 (HER2/neu) and progesterone receptor positivities. Partial response was obtained after four cure chemotherapy (adriamycin and cyclophosphamide). Then, she underwent a modified radical mastectomy with axillary lymph node dissection (level III). Grossly, a white-tan, solid, ill-defined tumor with $5 \mathrm{~cm}$ diameter located in the upper inner and outer quadrant of the breast was detected. Central portion of the tumor showed necrotic and hemorrhagic changes. Microscopic examination revealed poorly differentiated squamous cell carcinoma (SCC) having intraductal epithelial hyperplasia with squamous cell metaplasia and multiple small tumor foci at the periphery. The tumor had patchy necrotic, hemorrhagic and fibrotic areas representing regressive changes due to chemotherapy effect. Immunohistochemically, the tumor stained diffusely with CK7, CK8, CK19, HMW-CK and E-cadherin, whereas focally with CEA. Estrogenand progesterone receptors and c-erbB-2 were negative in the tumor. Five out of 20 lymph nodes dissected from the specimen were metastatic. Clinically, other organs were ruled out as the originating site of the tumor. She had taken oral chemotherapy (capecitabine) after surgery and has been living healthy for one year.

Key words: Primary squamous cell carcinoma; the breast; immunohistochemistry; differential diagnosis.
\end{abstract}

Sağ memesinde hızı büyüyen kitle yakınmasıyla başvuran 68 yaşında postmenopozal kadın hastaya tru-cut biyopsisi, lezyonun infiltratif yapısı ve immunohistokimyasal olarak c-erbB-2 (HER2/neu) ve progesteron reseptör pozitifliğine dayanarak "invaziv duktal karsinom" tanısı kondu. Hasta dört kür kemoterapiye (adriyamisin ve siklofosfamid) kısmi yanıt verdi. Kemoterapi sonrası modifiye radikal mastektomi ve aksiller lenf nodu diseksiyonu (level III) uygulandı. Makroskopik olarak üst iç ve diş kadranda $5 \mathrm{~cm}$ çaplı, kirli beyaz, solid, düzensiz sınırlı, merkezi kısmı nekrotik ve hemorajik tümör saptandı. Mikroskopik olarak kötü diferansiye skuamöz hücreli karsinom (SCC) niteliğindeki tümör çevresinde skuamöz metaplazili intraduktal epitelial hiperplazi ve multipl küçük SCC odakları gözlendi. Tümör, kemoterapiye bağlı regresyonu yansıtan nekrotik, hemorajik ve fibrotik alanlar içermekte idi. Deri tutulumu izlenmedi. İmmunohistokimyasal olarak tümörde CK7, CK8, CK19, HMW-CK ve E-cadherin diffüz, CEA fokal pozitifti. Östrojen ve progesteron reseptörleri ve c-erbB-2 negatifti. Materyalden ayıklanan 20 lenf nodundan beşi metastatikti. Klinik olartak skuamöz hücreli karsinomun gelişebileceği diğer organlar tarandı ve başka bir yerde herhangi bir tümör görülmedi. Operasyon sonrası oral kemoterapi (kapesitabin) alan hasta, bir yıldır sağlıklı bir şekilde yaşamını sürdürmektedir.

Anahtar sözcükler: Primer skuamöz hücreli karsinom; meme; immunohistokimya; ayırıcı tanı.
Primary squamous cell carcinoma (SCC) of the breast is a rare tumor classified as one of the metaplastic carcinomas of the breast. Its incidence is less than $0.1 \%$ of all ductal carcinomas. ${ }^{[1-18]}$ Its clinical features and radiological appearances are not specific. ${ }^{[3]}$
We present a 68-year-old postmenopausal woman with a rapidly growing right breast mass diagnosed with primary SCC of the breast. We have discussed immunohistochemical features of this rare tumor with respect to its differential diagnosis from invasive ductal 


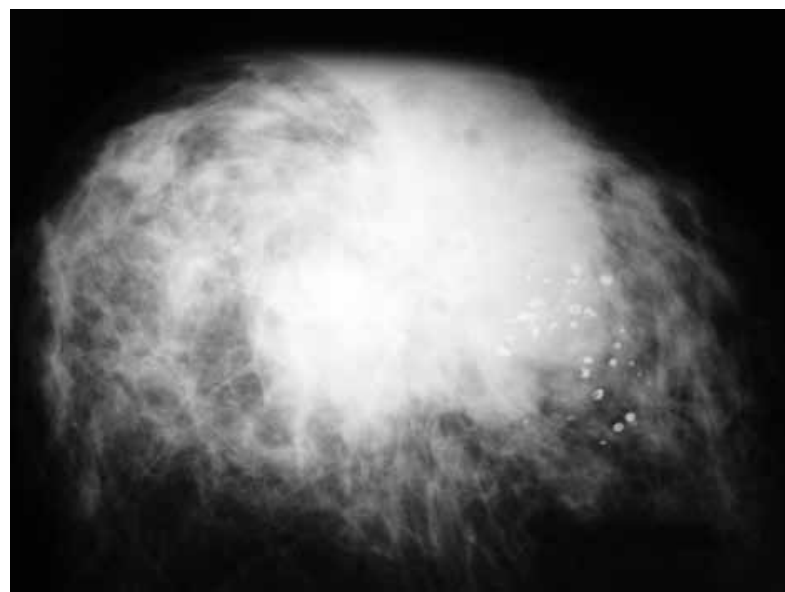

Fig. 1. Nonhomogeneous mass with lobular contour, spiculae formation and microcalcifications in the upper outer quadrant of the right breast at mammography.

carcinoma and cutaneous squamous cell carcinoma. Additionally, effects of neoadjuvant chemotherapy on this tumor have also been discussed.

\section{CASE REPORT}

A 68-year-old post-menopausal woman presented with a rapidly growing mass in her right breast. Her medical or familial history was unremarkable. Physical examination revealed a well-circumscribed and firm mass approximately $8 \mathrm{~cm}$ in diameter. Overlying skin was edematous in appearance and there was no nipple discharge. Mammography showed an 8x7 cm nonhomogeneous mass with lobular contour and spiculae formation in the upper outer quadrant of the right breast. Microcalcifications were detected within the tumor (Fig. 1). A tru-cut biopsy was performed and the tumor was diagnosed as "invasive ductal carcinoma" owing to infiltrative pattern with no apparent keratinization (Fig. 2). Immunohistochemically, reactivity to progesterone receptor and c-erbB-2 seen in small tumoral areas also gave support to this diagnosis (Figs. 3, 4).

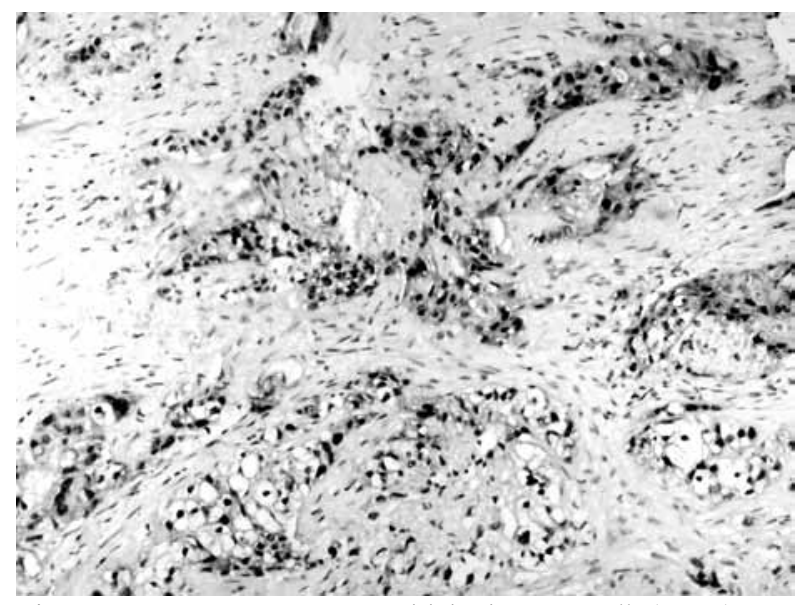

Fig. 3. Progesteron receptor positivity in tumor cells (x 100).

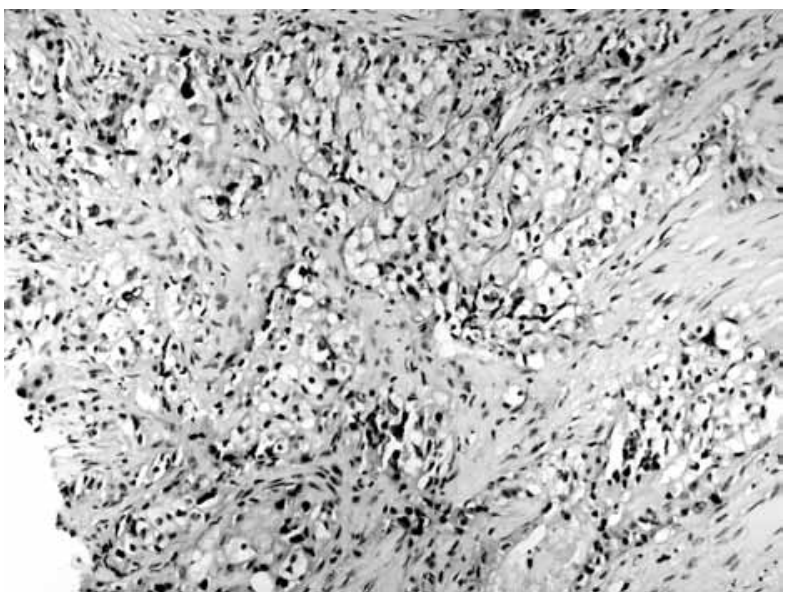

Fig. 2. Atypical tumoral cells with abundant cytoplasm (H-E $\times 100)$.

A number of findings such as decreasing tumor size from $8 \mathrm{~cm}$ to $5 \mathrm{~cm}$, axillary lymphadenopathy measuring $4 \mathrm{~cm}$ to $2 \mathrm{~cm}$ and relieving skin edema were all thought to be indicators of partial clinical response to four cure chemotherapy comprising adriamycin and cyclophosphamide. Then, she underwent a modified radical mastectomy of the right breast with ipsilateral axillary lymph node dissection (level III).

Grossly, a white-tan, solid, ill-defined tumor measuring $5 \mathrm{~cm}$ in diameter located in upper inner and outer quadrant of the breast was detected. Its central portions were necrotic and hemorrhagic.

Microscopic examination revealed an invasive tumor comprising of cells with eosinophilic cytoplasm and enlarged hyperchromatic nuclei. In some areas the tumor produced keratinous material. Mostly, the tumor had poorly differentiated and contained microcalcifications (Fig. 5). At the periphery of the main invasive tumor, fibrocystic changes including ductal epithelial hyperplasia with squamous cell metaplasia and small multiple SCC foci were present. The tumor had patchy necrotic, hemorrhagic and fibrotic areas representing

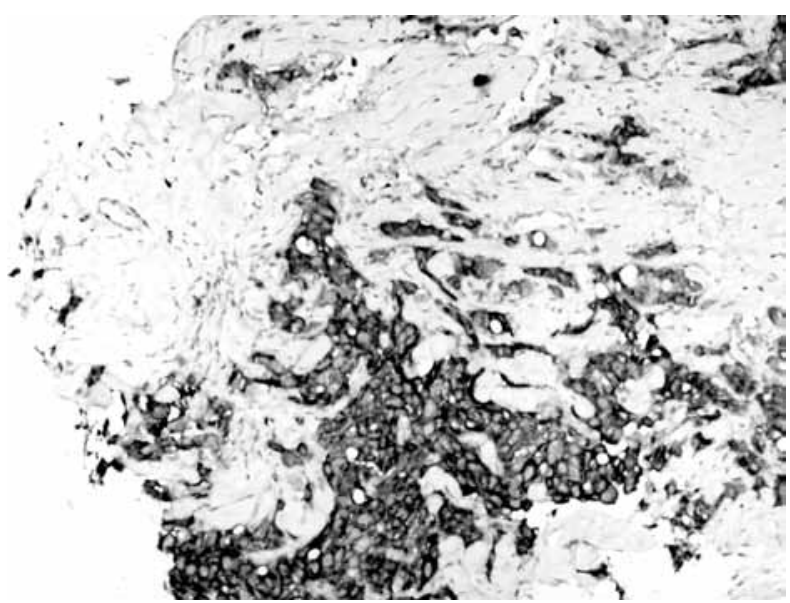

Fig. 4. C-erbB-2 positivity in tumor cells (x 100). 


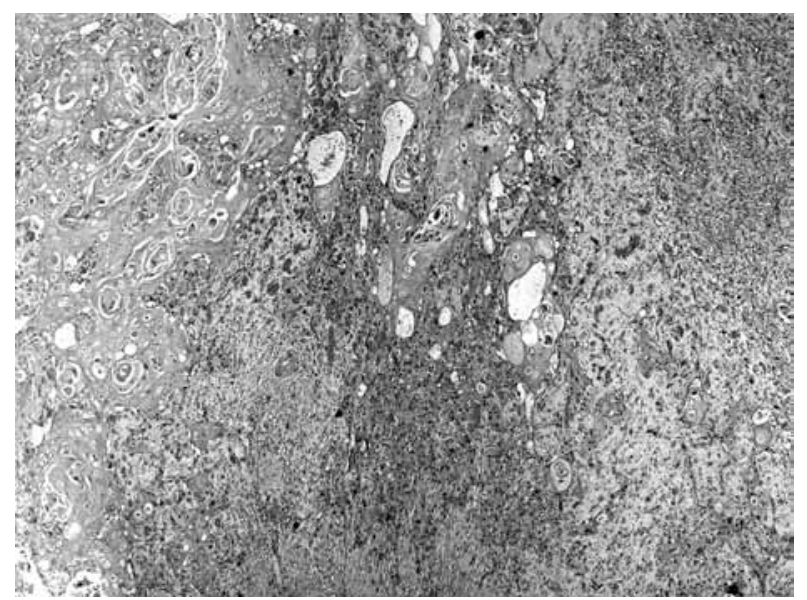

Fig. 5. An invasive tumor with cells containing eosinophilic cytoplasm, enlarged hyperchromatic nuclei and keratinous material ( $H-E x 40)$.

regressive changes due to chemotherapy effect, though overlying skin was not affected.

Immunohistochemically, CK7 (CK7 OV-TL, Novocastra, Newcastle, UK), CK8 (LMWCK 35ßH11, Dako, Carpinteria, CA, USA) and CK19 (MU-246-UC, BioGenex, San Ramon, CA, USA) stained the tumor cells but not the overlying normal epidermis which acted as an internal control. On the contrary, HMW-CK (34 $\beta E 12$, Dako, Carpinteria, CA, USA) was positive in tumor cells along with the normal epidermis (Fig. 6). E-cadherin (NCH-38, Dako, Fremont, CA, USA) was positive in tumoral cells. CEA (monoclonal,11-7, Dako, Carpinteria, CA, USA) was focally positive in tumor. As for the steroid receptors, the tumor was negative for estrogen and progesterone receptors (1D5 and PR88, respectively, BioGenex, San Ramon, CA, USA), also negative for cerbB-2 (CB11, BioGenex, San Ramon, CA, USA).

Metastases were seen in 4 out of 13 lymph nodes dissected from the main mastectomy specimen and in 1 of 7 lymph nodes from level III axillary dissection material.

Clinically, oral cavity, esophagus, larynx, lungs, skin, genital tract and bladder were sought for as a possible primary site but no tumor was found in these organs or sites. Therefore, the tumor was considered as "primary poorly differentiated squamous cell carcinoma of the breast".

The patient was given oral chemotherapy (capecitabine) after surgery and has been living with no sign of disease anywhere for one year after the surgery.

\section{DISCUSSION}

Primary squamous cell carcinoma (SCC) is a very rare tumor of the breast. ${ }^{[1-18]}$ Although its histogenesis is unclear, some authors suggest it may originate from complete metaplasia of ductal epithelium. . $^{[1,3,4,14]}$ Development of SCC from metaplastic epithelium can
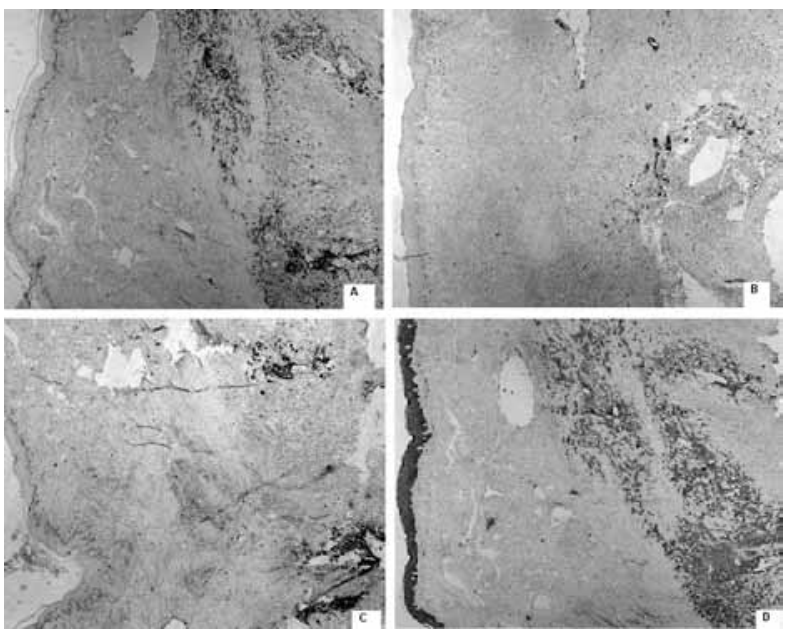

Fig. 6. (a) CK7, (b) CK8 and (c) CK19 stained the tumor cells but not the overlying normal epidermis, (d) HMW-CK was positive in tumor cells and the normal epidermis $(x 40)$.

also be considered as a complication of chronic breast inflammation, for example due to the presence of breast implants. ${ }^{[4]}$ An alternate theory is that the tumor arises from foci of squamous metaplasia within a pre-existing adenocarcinoma of the breast. ${ }^{[3,17]}$ Features of the presented case such as squamous metaplasia in nontumoral ductal epithelium and multiple small invasive SCC foci around the main invasive tumor mass and immunohistochemical findings all support the first theory which favors metaplastic background for the neoplastic development. Cytokeratin profile in our case, especially diffuse CK7, CK8, CK19 and focal CEA positivity gives support to ductal origin of the tumor. ${ }^{[19-22]}$ Moreover, the tumor displayed membranous E-cadherin staining which is characteristic of the ductal immunophenotype, ${ }^{[23,24]}$ while HMW CK positivity, histologic appearance and lamellar keratin formation are typical properties of squamous cells.

It is generally considered that before arriving at the diagnosis of primary SCC of the breast, four essential conditions should be present: a) Exclusion of SCC of the overlying skin of the breast or nipple, b) exclusion of metastasis from extramammary primary SCC, c) clear predominance (more than $90 \%$ ) of areas with SCC, d) absence of other neoplastic ductal or mesenchymal elements. ${ }^{[3-6,10]}$

No specific clinical or radiological findings of squamous cell carcinoma of the breast have been described. $[3,4,10]$ Squamous cell carcinoma of the breast predominantly affects post-menopausal women ${ }^{[4]}$ but a few patients in their gestational or lactating period have also been reported. ${ }^{[9]}$ The patients' average age is similar to those of common forms of breast cancer in some series but older in the others..$^{[1,2,4,9,10]}$ The tumor's presentation is nearly always a breast lump ${ }^{[4,8]}$ and sometimes as a breast abscess, chronic breast cysts or nipple 
discharge. ${ }^{[5,7,11,12,14,15]}$ Mostly, rapidly growing necrotic, cystic tumoral mass is reported. ${ }^{[1,2,4,7,8,12-15,17]}$ Squamous cell carcinoma tends to be somewhat larger at presentation than other types of breast carcinoma with more than half of the reported cases in excess of $5 \mathrm{~cm}$ in diameter. ${ }^{[5,7,9-12,17]}$ In our case, after the neo-adjuvant chemotherapy, the diameter of the tumor decreased to $5 \mathrm{~cm}$. Calcification or cystic changes can sometimes be seen radiographically. ${ }^{[4,5,7,8,10,17]}$ Our patient's clinical and mammographic findings were similar to those described at recent reports.

Microscopically, primary SCC of the breast is composed of infiltrative nests of atypical epithelial cells with irregular and hyperchromatic nuclei. Tumor may have variable amounts of keratinous material. It may have been associated with DCIS or squamous metaplasia of ductal epithelium at the periphery of the invasive carcinoma, ${ }^{[2,4,6,12,17]}$ Estrogen and progesterone receptors are almost always reported to be negative. ${ }^{[1-18]} \mathrm{c}-\mathrm{erbB}-2$ is also usually not overexpressed or amplified but some cases with c-erbB-2 positivity have been seen. ${ }^{[3,6,18]}$

Our patient's tru-cut biopsy specimen which was taken before the chemotherapy contained small tumoral areas with infiltrative cell groups having no keratin formation. Additionally, the tumor immunohistochemically showed positivity for c-erbB-2 and progesterone receptor which suggested it to be an "invasive ductal carcinoma". Primary SCC of the breast can be confused with invasive ductal carcinoma in tru-cut biopsy specimen when the tumor is small or very infiltrative or taken from less differentiated portions of the neoplasm which has no keratinization. In the tumor on mastectomy specimen, noticeable disappearance of the reactivity for c-erbB-2 and progesterone receptor can be explained by the chemotherapy effect as in other types of breast tumors. ${ }^{[25]}$

As for the differential diagnosis between cutaneous SCC and primary SCC of the breast, the tumor should have no association with overlying epidermis or cutaneous appendages. Alternatively, immunohistochemistry is also a useful tool. Both of these tumor types are positive with HMW-CK wheras primary breast tumors generally have CK 19, CK 7 and CK 8 staining contrary to the cutaneous SCC. ${ }^{[19-22]}$

The initial treatment of choice is surgery and there is still no consensus concerning adjuvant therapy. ${ }^{[3-5,7,8,10-}$ 12,14] Some studies suggest the use of radiotherapy ${ }^{[5,8,11,14]}$ or chemotherapy, ${ }^{[3,5,8,9,11,14]}$ but others find no difference in outcome with adjuvant radiotherapy. ${ }^{[10,16,17]} \mathrm{Neo}-$ adjuvant chemotherapy and radiotherapy have been reported to downstage the tumor. ${ }^{[7,8]}$ Our patient had a partial response to neoadjuvant chemotherapy in the sense that the size of the primary tumor mass and axillary LAP decreased, skin edema resolved. She had taken additional chemotherapy after surgery.
Prognostic factors of this tumor are controversial. The relationship between prognosis and pattern or degree of differentiation of primary SCC of the breast is uncertain. Age below 40 years, large tumor size and the presence of lymph node metastasis are reported to be markers of poor prognosis..$^{[4,5,8,10,16]}$ The prognosis and clinical course of SCC of the breast is still mostly unknown ${ }^{[4,8]}$ possibly due to the fewness of well-documented cases. There are some studies suggesting a more aggressive behavior than common breast carcinomas ${ }^{[3,5,9,10,16-18]}$ along with the reports stating a course similar to invasive ductal carcinomas or even an indolent course. ${ }^{[4,7]}$

In conclusion, it should be noted that there is a great clinical, pathologic and therapeutic heterogeneity among different studies since the number of patients with primary SCC of the breast is insufficient to make appropriate generalizations.

\section{REFERENCES}

1. Tavassoli FA. Infiltrating carcinoma: special types. In: Tavassoli FA, editor. Pathology of the breast. 2nd ed. Stamford, CT: Appleton \& Lange; 1999. p. 481-570.

2. O'Malley FP, Pinder SE. Invasive carcinoma: special types. In: Harris GC, Pinder SE, O'Malley FP, editors. Breast pathology. 1st ed. Philadelphia, PA: Churchill Livingstone Elsevier; 2006. p. 201-23.

3. Hennessy BT, Krishnamurthy S, Giordano S, Buchholz TA, Kau SW, Duan Z, et al. Squamous cell carcinoma of the breast. J Clin Oncol 2005;23:7827-35.

4. Cardoso F, Leal C, Meira A, Azevedo R, Mauricio MJ, Leal da Silva JM, et al. Squamous cell carcinoma of the breast. Breast 2000;9:315-9.

5. Behranwala KA, Nasiri N, Abdullah N, Trott PA, Gui GP. Squamous cell carcinoma of the breast: clinico-pathologic implications and outcome. Eur J Surg Oncol 2003;29:386-9.

6. Karamouzis MV, Fida A, Apostolikas N, Rigatos G. A case of HER-2(+) squamous cell breast carcinoma: an unusual presentation of an unusual clinical entity. Eur J Surg Oncol 2006;32:1250-1.

7. Moisidis E, Ahmed S, Carmalt H, Gillett D. Primary squamous cell carcinoma of the breast. ANZ J Surg 2002;72:65-7.

8. Menes T, Schachter J, Morgenstern S, Fenig E, Lurie $H$, Gutman H. Primary squamous cell carcinoma (SqCC) of the breast. Am J Clin Oncol 2003;26:571-3.

9. Rokutanda N, Iino Y, Yokoe T, Maemura M, Horiguchi J, Takei $\mathrm{H}$, et al. Primary squamous cell carcinoma of the breast during lactation: a case report. Jpn J Clin Oncol 2000;30:279-82.

10. Aparicio I, Martínez A, Hernández G, Hardisson D, De Santiago J. Squamous cell carcinoma of the breast. Eur J Obstet Gynecol Reprod Biol 2008;137:222-6.

11. Gupta C, Malani AK, Weigand RT, Rangineni G. Pure primary squamous cell carcinoma of the breast: a rare presentation and clinicopathologic comparison with usual ductal carcinoma of the breast. Pathol Res Pract 2006;202:465-9.

12. Shigekawa $T$, Tsuda $H$, Sato $K$, Ueda $S$, Asakawa $H$, Shigenaga $R$, et al. Squamous cell carcinoma of the breast in the form of an intracystic tumor. Breast Cancer 2007;14:109-12.

13. Yashar P, Sepahdari AR, Mahjoubi FD. Primary squamous cell carcinoma of the breast in an adult woman. Breast J 2006;12:571-2. 
14. Tan YM, Yeo A, Chia KH, Wong CY. Breast abscess as the initial presentation of squamous cell carcinoma of the breast. Eur J Surg Oncol 2002;28:91-3.

15. Gupta C, Malani AK. Abscess as initial presentation of pure primary squamous cell carcinoma of the breast. Clin Breast Cancer 2006;7:180.

16. Rayson D, Adjei AA, Suman VJ, Wold LE, Ingle JN. Metaplastic breast cancer: prognosis and response to systemic therapy. Ann Oncol 1999;10:413-9.

17. Miura H, Taira O, Hiraguri S, Maeda J, Kato H. Recurrent squamous cell carcinoma of the breast with undifferentiated features: report of a case. Surg Today 2002;32:891-5.

18. Reis-Filho JS, Milanezi F, Steele D, Savage K, Simpson PT, Nesland JM, et al. Metaplastic breast carcinomas are basallike tumours. Histopathology 2006;49:10-21.

19. Megha T, D'Amuri A, Benvenuto A, De Santi MM, De Luca F, Civitelli S. Primary squamous cell carcinoma of the breast: a case report. [Article in Italian] Pathologica 2004;96:45-8. [Abstract]

20. Ciocca V, Bombonati A, Gatalica Z, Di Pasquale M, Milos A, Ruiz-Orrico A, et al. Cytokeratin profiles of male breast cancers. Histopathology 2006;49:365-70.
21. Abd El-Rehim DM, Pinder SE, Paish CE, Bell J, Blamey RW, Robertson JF, et al. Expression of luminal and basal cytokeratins in human breast carcinoma. J Pathol 2004;203:661-71.

22. Gal-Gombos EC, Esserman LE, Recine MA, Poppiti RJ Jr. Large-needle core biopsy in atypical intraductal epithelial hyperplasia including immunohistochemical expression of high molecular weight cytokeratin: analysis of results of a single institution. Breast J 2002;8:269-74.

23. Bratthauer GL, Wheeler DT, Tavassoli FA. The ductal phenotypic expression of the E-cadherin/catenin complex in tubulolobular carcinoma of the breast: an immunohistochemical and clinicopathologic study. Mod Pathol 2008;21:1058.

24. Choi YJ, Pinto MM, Hao L, Riba AK. Interobserver variability and aberrant E-cadherin immunostaining of lobular neoplasia and infiltrating lobular carcinoma. Mod Pathol 2008;21:1224-37.

25. Quddus RM, Sung JC, Zhang C, Pasqueriello T, Eklund M, Steinhoff MM. HER-2/neu expression in locally advanced breast carcinomas: pre-and post-neoadjuvant chemotherapy. Breast Cancer 2005;12:294-8. 